\title{
Rapid identification of Streptococcus intermedius by PCR with the ily gene as a species marker gene
}

\author{
TAKATSUGU GOTO*§, HIDEAKI NAGAMUNE*, AIKO MIYAZAKI*, YOSHIAKI KAWAMURA \\ OOKI OHNISHI*, KANAKO HATTORI*, KAZUTO OHKURA*\|, KAZUAKI MIYAMOTO§, \\ SHIGERU AKIMOTO§, TAKAYUKI EZAKI†, KATSUHIKO HIROTA $\uparrow$, YOICHIRO MIYAKE†, \\ TAKUYA MAEDA* and HIROKI KOURAI* \\ * Department of Biological Science and Technology, Faculty of Engineering, University of Tokushima, Minami- \\ josanjima cho, Tokushima 770-8506, †Department of Oral Microbiology, School of Dentistry, University of \\ Tokushima, Kuramotocho, Tokushima 770-8504, \$Department of Microbiology, School of Medicine, Gifu \\ University, Tsukasa-machi, Gifu 500-8705, §Department of Microbiology, Wakayama Medical University, \\ Kimiidera, Wakayama 641-0012 and ||Department of Applied Biological Sciences, Faculty of Agricultural \\ Sciences, Nagoya University, Furo-cho, Chikusa-ku, Nagoya 464-8601, Japan
}

\begin{abstract}
Streptococcus intermedius belongs to the anginosus group of streptococci (AGS) and is associated with endogenous infections leading to abscesses in the oral cavity and at deepseated sites, such as the brain and liver. Two other species, $S$. anginosus and $S$. constellatus, and some presently unnamed taxa, are also classified as AGS. Recently, $S$. constellatus subsp. pharyngis, a new subspecies with biochemical characteristics similar to $S$. intermedius, was described with the potential for causing confusion when trying to identify isolates of these two species routinely with commercial identification kits, such as Rapid ID32 Strep and Fluo-Card Milleri. To correctly identify $S$. intermedius, this study attempted to develop an accurate PCR identification system with the ily gene as a species marker. This approach relies on amplification of an 819-bp fragment of the ily gene and its $3^{\prime}$-flanking region and is shown here to be specific for $S$. intermedius strains among all other streptococcal species. Moreover, this PCR system was applicable in direct rapid PCR with whole bacterial cells and TaKaRa Z-Taq ${ }^{\mathrm{TM}}$ (TaKaRa), a highly efficient DNA polymerase, as the template and DNA amplification enzyme, respectively.
\end{abstract}

\section{Introduction}

Anginosus group streptococci (AGS), formerly called 'Streptococcus milleri', are recognised as a part of normal human oral flora and are opportunist pathogens in endogenous infections [1-8]. AGS are currently classified as $S$. anginosus, $S$. constellatus subsp. constellatus, $S$. constellatus subsp. pharyngis and $S$. intermedius $[9,10]$. S. intermedius exhibits a tropism for infections of deep sites such as the brain and liver [11] and is also associated with periodontitis [12]. In spite of the clinical significance of $S$. intermedius reported previously $[7,8,11,12]$, it is difficult for the clinical laboratory to identify $S$. intermedius among AGS isolates because of the paucity of differential biochemical tests [11]. Indeed, it is known that rapid

Received 10 April 2001; revised version accepted 16 August 2001.

Corresponding author: Dr H. Nagamune (e-mail: nagamune (abio.tokushima-u.ac.jp). systems that utilise standard phenotypic tests, such as API20 Strep and Rapid ID32 Strep (bioMérieux) are not satisfactory for the accurate identification of AGS at the species level $[13,14]$. Specifically, there is potential confusion between $S$. intermedius and $S$. constellatus subsp. pharyngis, which have similar phenotypes. Fluo-Card Milleri (Key Scientific), which is a biotyping kit specifically developed for identification of AGS [15], also misidentifies $S$. constellatus subsp. pharyngis because its phenotype is similar to that of $S$. intermedius. Therefore, to identify $S$. intermedius with such commercial kits, some additional tests, for sialidase production, Lancefield grouping and haemolysis on the animal blood agar, are necessary to distinguish it from $S$. constellatus subsp. pharyngis. Moreover, although some studies have developed genetic identification methods for AGS [9, 16, 17], more rapid and accurate methods are desirable for the routine laboratory. A previous study reported that a human-specific cytolysin, intermedilysin (ILY), was secreted by a strain of $S$. intermedius UNS46 isolated 
from human liver abscess [18]. It has been suggested recently that ILY is likely to be a pathogenic or triggering factor of significance in inducing deep-seated infections with $S$. intermedius and that the ily gene is potentially useful for the identification of $S$. intermedius among AGS [19]. However, to use the ily gene as a species marker gene of $S$. intermedius in clinical diagnosis, further examination of the distribution of the ily gene and any closely related genes among other human isolates of streptococci is essential. The present study attempted to confirm the appropriateness of the ily gene as a species marker, to design an improved ily gene-specific PCR primer set that can specifically amplify the ily gene and its 3 '-flanking region in $S$. intermedius in contrast to other AGS, other species groups of streptococci and some related genera, and to apply the primer set to a rapid direct colony PCR system. The accuracy of this PCR method was compared with the current reference identification method described by Whiley et al. [11] and a commercial biochemical test kit (Rapid ID32 Strep).

\section{Materials and methods}

\section{Bacterial strains and culture conditions}

Type strains of each group within the genus Streptococcus: S. acidominius (GTC234), S. agalactiae (GTC1234), S. alactolyticus (GTC432), S. anginosus (NCTC10713), S. bovis (GTC235), S. canis (GTC423), S. constellatus subsp. constellatus (NCDO2226), $S$. constellatus subsp. pharyngis (MM9889a), S. criceti (GTC242), S. cristatus (GTC631), S. difficilis (GTC730), S. downei (GTC632), S. dysgalactiae subsp. equisimilis, (GTC842), S. dysgalactiae subsp. dysgalactiae (GTC431), S. equi subsp. equi (GTC269), S. equi subsp. zooepidemicus (GTC542), S. equinus (GTC 246), S. ferus (GTC 279), S. gallolyticus (GTC 809), S. gordonii (GTC 497), S. hyointestinalis (GTC 496), S. hyovaginalis (GTC 1229), S. infantis (GTC 849), S. iniae (GTC 244), S. intermedius (NCDO2227), S. intestinalis (GTC537), S. macacae (GTC 538), S. macedonicus (GTC 1230), S. mitis (GTC 495), $S$. mutans (GTC 218), S. oralis (GTC 276), S. parasanguinis (GTC 498), S. parauberis (GTC 539), $S$. peroris (GTC 848), $S$. phocae (GTC 776), $S$. pleomorphus (GTC 690), S. pneumoniae (GTC 261), $S$. porcinus (GTC 543), S. pyogenes (GTC 262), S. ratti (GTC 245), S. salivarius (GTC 215), S. sanguinis (GTC 217), S. sobrinus (GTC 278), S. suis (GTC 430), $S$. thermophilus (GTC 241), S. thoraltensis (GTC 1231), S. uberis (GTC 271) and S. vestibularis (GTC 488); and the type strains of related genera: Staphylococcus aureus (GTC286), Staph. epidermidis (GTC 289), Enterococcus faecalis (GTC 228), E. faecium (GTC 227), Lactococcus lactis (GTC 232) and Gemella haemolysans (GTC 219) were used as the species standards. Fifty-five clinical isolates of AGS from human tonsillitis (TW4466, TW4468, TW4469, TW4470, TW4471, TW4472, TW4473, TW4474,
TW4475, TW4476, TW4477, TW4478, TW4479, TW4480, TW4481, TW4482, TW4483, TW4484, TW4485, TW4486, TW4487, TW4488, TW4489, TW4490, TW4491, TW4492, TW4493, TW4494, TW4495, TW4496, TW4497, TW4498, TW4499, TW4500, TW4501, TW4502, TW4504, TW4505, TW4506, TW4507, TW4508, TW4509, TW4510, TW4511, TW4512, TW4513, TW4514, TW4515, TW4516, TW4517, TW4518, TW4519, TW4520, TW4521 and TW4522) and 33 reference strains from various sites $[10,19,20]$ including $S$. anginosus (AS/ JM4, EF222, KR461, KR687, HW31, NCTC11169, POOLE PHLS457, R84/4972, R88/111 and 153ii), $S$. anginosus group 2 (MAS 624), S. constellatus subsp. constellatus (F436, NCTC11063, NMH4, NMH6, R87/3795, W277, 47, 1340, 1792b and 3206443), S. constellatus subsp. pharyngis (I751), S. intermedius (AC4720, AM47, A4676a, DP102, GN6146, HARDYDAVID T1, PC574, PC941, UNS35, UNS38(=38) and UNS46) were also used. TW strains and accompanying Lancefield grouping and Rapid ID32 Strep data were kindly provided by Dr Ken Kikuchi, Tokyo Women's Medical College. Strains were maintained on horse blood 5\% v/v agar based on Brain Heart Infusion (BHI) Broth (Difco Laboratories) at $37^{\circ} \mathrm{C}$ under anaerobic conditions except $S$. pneumoniae and $S$. aureus which were cultured at $37^{\circ} \mathrm{C}$ under aerobic conditions.

\section{Phenotypic characterisation of $A G S$}

Production of enzymes $\alpha$-arabinosidase, $\alpha$-L-fucosidase, $\beta$-D-fucosidase, $\alpha$-D-galactosidase, $\beta$-D-galactosidase, $\alpha$-D-glucosidase, $\beta$-D-glucosidase, $\beta$ - $N$-acetylgalactosaminidase, $\beta$ - $N$-acetylglucosaminidase and sialidase was determined with fluorogenic substrates as described previously [11]. Haemolysis was observed on horse blood agar.

\section{Preparation of bacterial genomic DNA}

Bacterial genomic DNA was prepared as follows. All bacterial cells cultured in $20 \mathrm{ml}$ of BHI broth containing $\mathrm{D}(+)$-glucose $0.5 \% \mathrm{w} / \mathrm{v}$ for $18 \mathrm{~h}$ were collected by centrifugation and washed with $0.8 \mathrm{ml}$ of $\mathrm{TE}$ buffer, $\mathrm{pH}$ 8.0. The washed cells were suspended in $0.1 \mathrm{ml}$ of TE, $\mathrm{pH} 8.0$, and mixed with $10 \mu \mathrm{l}$ of lysozyme $50 \mathrm{mg} / \mathrm{ml}$ in TE and $3 \mu \mathrm{l}$ of RNAase $\mathrm{I} 10 \mathrm{mg} / \mathrm{ml}$ in sterile water. The enzyme reaction was allowed to proceed at $37^{\circ} \mathrm{C}$ for $30 \mathrm{~min}$, then $0.5 \mathrm{ml}$ of the lysis mixture containing guanidine isothiocyanate $60 \% \mathrm{w} / \mathrm{v}$, $100 \mathrm{mM}$ EDTA sodium salt $(\mathrm{pH} 8.0)$ and N-laurylsarcosine $0.5 \% \mathrm{w} / \mathrm{v}$ was mixed with each reaction mixture and left at room temperature for $10 \mathrm{~min}$ to complete the cell lysis. After the addition of $0.25 \mathrm{ml}$ of cold $7.5 \mathrm{M}$ ammonium acetate, the mixture was mixed and placed on ice for $10 \mathrm{~min}$. Subsequently, $0.5 \mathrm{ml}$ of chloroform:isoamylalcohol $(24: 1)$ was mixed thoroughly with each reaction mixture. Then, the mixture was centrifuged at $13000 \mathrm{rpm}$ for $10 \mathrm{~min}$ in a microcentrifuge. A $0.7-\mathrm{ml}$ sample of the supernate 
was transferred to a new microcentrifuge tube and mixed with $0.378 \mathrm{ml}$ of cold isopropanol. After gently mixing by inverting the tube for $1 \mathrm{~min}$, the mixture was centrifuged at $13000 \mathrm{rpm}$ for $2 \mathrm{~min}$ and the supernate was discarded. Precipitated DNA was resuspended in $0.2 \mathrm{ml}$ of TE. After the addition of $0.5 \mathrm{ml}$ of cold absolute ethanol to the DNA solution, the mixture was placed at $-80^{\circ} \mathrm{C}$ for $15 \mathrm{~min}$, then centrifuged at $13000 \mathrm{rpm}$ for $3 \mathrm{~min}$. The supernate was removed, the precipitated DNA was air-dried for $15 \mathrm{~min}$, dissolved in $0.1 \mathrm{ml}$ of $\mathrm{TE}$ and stored at $4^{\circ} \mathrm{C}$ until required. The concentration and quality of extracted DNA were checked by agarose gel electrophoresis.

\section{Dot-blot hybridisation}

The ily gene fragment of $1502 \mathrm{bp}$ was amplified by PCR with primers: ILY-N terminal Fw, 5'-GAAA CACCTACCAAACCAAAAGCAGCTCAA-3', ILY-C end $\mathrm{Bw}, 5^{\prime}$-GCTTAATCAGTGTTATCTTTCACAAC$3^{\prime}$ and plasmid pILYw carrying the whole ily gene (Fig. 1). This fragment was labelled with $\alpha-\left[{ }^{32} \mathrm{P}\right]-\mathrm{dCTP}$ with a Random Primer DNA Labeling Kit Ver.2 (TaKaRa, Tokyo, Japan), and then used as a probe in the following dot-blot hybridisation system to evaluate the distribution of homologue(s) of the ily gene among other streptococci (48 strains) and several species from related genera before developing a molecular approach suitable for use in a routine laboratory. Each extracted bacterial genomic DNA (100 ng) was blotted on a nylon membrane (Gene screen plus; NEN research) pre-equilibrated with $10 \times \mathrm{SSC}$ with a blotting apparatus (Milliblot-V Jr; Millipore). The blotted membranes were treated with $0.5 \mathrm{M} \mathrm{NaOH}$ for 1 min and with $1 \times \mathrm{SSC}$ containing $0.2 \mathrm{M}$ Tris- $\mathrm{HCl}(\mathrm{pH} 7.5)$ for $1 \mathrm{~min}$. After the denaturation step, the membranes were washed with $2 \times$ SSC twice and dried on filter paper. The blotted membranes were prehybridised at $55^{\circ} \mathrm{C}$ for $1 \mathrm{~h}$ in the prehybridisation solution $(6 \times \mathrm{SSC}$ containing skimmed milk $5 \% \mathrm{w} / \mathrm{v}$, sodium azide
$0.02 \% \mathrm{w} / \mathrm{v}$ and SDS $1 \% \mathrm{w} / \mathrm{v})$. Subsequently, the $\left[{ }^{32} \mathrm{P}\right]-$ labelled probe solution (final activity $c .5 \times 10^{5}$ $\mathrm{cpm} / \mathrm{ml}$ ) and $0.2 \mathrm{mg}$ of salmon sperm DNA were added to $0.5 \mathrm{ml}$ of distilled water and heat-treated at $95^{\circ} \mathrm{C}$ for $3 \mathrm{~min}$ and immediately chilled to make the working probe solution. After prehybridisation, the working probe solution was added to the prehybridisation solution and hybridisation was allowed to proceed at $55^{\circ} \mathrm{C}$ (low stringency) or $68^{\circ} \mathrm{C}$ (high stringency) overnight. Then, the membranes were washed twice in $2 \times$ SSC containing SDS $1 \%$ at room temperature for $5 \mathrm{~min}$, for $30 \mathrm{~min}$ in $0.2 \times \mathrm{SSC}$ containing SDS $1 \%$ at a temperature corresponding to that used for the hybridisation. Air-dried membranes were exposed to $\mathrm{X}$-ray films at $-80^{\circ} \mathrm{C}$ overnight.

\section{PCR with extracted genomic DNA as the template}

The PCR primers specific for the ily gene used in the present study were as follows: ILY-4D Fw as the forward primer, 5'-CTCACCCTCAATCATGATGG TGC-3' and ILY-wholeC Bw as the reverse primer, 5'-CGACTCACTATAGGGAGATCAGCATGG-3'. The expected amplicon size was $819 \mathrm{bp}$ (Fig. 1). These primers were synthesised by the manufacturer on the basis of ORF and 3' flanking region of the ily gene sequence (DDBJ/EMBL/GenBank nucleotide sequence databases with the accession no. AB029317). PCR with the extracted genomic DNA as a template was peformed in a reaction mixture of $50 \mu \mathrm{l}$ final volume containing $1 \mu \mathrm{l}(150 \mathrm{ng})$ of each template genomic DNA in TE (pH 8.0), $1 \mu \mathrm{l}$ of $2 \mathrm{mM}$ each deoxyribonucleotide triphosphate (Perkin-Elmer), Taq DNA polymerase (Promega) $1 \mathrm{U}, 10 \mathrm{pmol}$ of each primer, $5 \mu \mathrm{l}$ of 10-fold concentrated PCR buffer (50 mM Tris- $\mathrm{HCl}$, $100 \mathrm{mM} \mathrm{NaCl}, 0.1 \mathrm{~mm}$ EDTA, $1 \mathrm{mM}$ DTT, glycerol $50 \%$ and Triton X-100 1\%) and $3 \mu \mathrm{l}$ of $25 \mathrm{mM} \mathrm{MgCl}_{2}$. Amplification was performed in a GeneAmp PCR System 2400 (Perkin-Elmer) programmed for 35 cycles as follows: $1 \mathrm{~min}$ of denaturation at $95^{\circ} \mathrm{C}, 1 \mathrm{~min}$ of

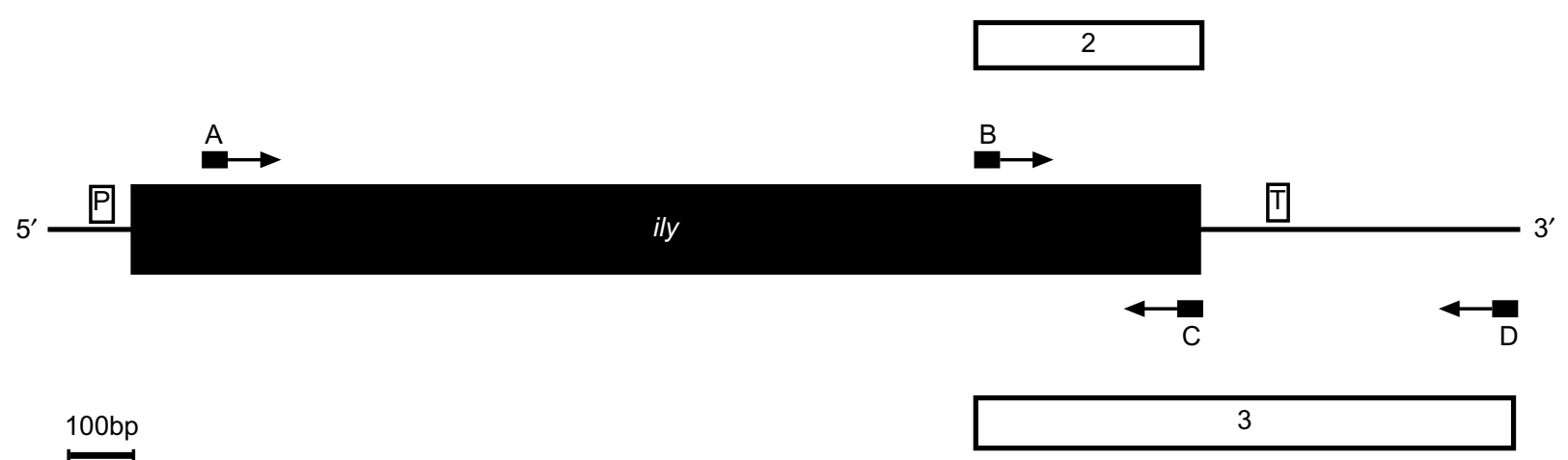

Fig. 1. Schematic representation of the location of primers, probes and S. intermedius-specific amplicon described in the present paper. A genomic fragment of $2212 \mathrm{bp}$ of $S$. intermedius including whole ily gene (GeneBank/EMBL/DDBJ no. AB029317) is shown. Primers: A, ILY-N terminal Fw; B, ILY-4D Fw; C, ILY-C end Bw; D , ILY-wholeC Bw. 1, the probe for dot-blot hybridisation of genomic DNA; 2, the probe for Southern blot hybridisation of PCR products; 3, S. intermedius-specific amplicon. Boxed $\mathrm{P}$ and $\mathrm{T}$ show the location of the promotor region and the terminator region of the ily gene, respectively. 
primer annealing at $55^{\circ} \mathrm{C}$ and 2 min of extension at $72^{\circ} \mathrm{C}$. The PCR products were analysed by electrophoresis in agarose $2.0 \%$ gels in a $0.5 \times$ TBE buffer system. AmpliTaq Gold ${ }^{\mathrm{TM}}$ (Perkin-Elmer) or TaKaRa $Z-\operatorname{Taq}^{\mathrm{TM}}$ (TaKaRa) DNA polymerase were used for PCR with extracted genomic DNA as a template, as required and detailed below.

\section{Direct colony PCR}

Direct detection from a single colony of $S$. intermedius strains was performed by PCR with Taq DNA polymerase or TaKaRa Z-Taq ${ }^{\mathrm{TM}}$. PCR with Taq DNA polymerase was performed as described above with a slight modification, i.e., an additional preheating step of a single colony as the template at $95^{\circ} \mathrm{C}$ for $10 \mathrm{~min}$ in the PCR reaction mixture before the PCR cycles. PCR with TaKaRa Z-Taq ${ }^{\mathrm{TM}}$ was performed in the reaction mixture of $50 \mu \mathrm{l}$ containing a single colony preheated at $95^{\circ} \mathrm{C}$ for $10 \mathrm{~min}$ as the template, $1 \mu \mathrm{l}$ of $2 \mathrm{mM}$ each deoxyribonucleotide triphosphate (PerkinElmer), TaKaRa Z-Taq ${ }^{\mathrm{TM}} 1 \mathrm{U}, 10$ pmol of the forward primer, 10 pmol of the backward primer and $5 \mu \mathrm{l}$ of $10 \times$ PCR buffer attached with TaKaRa Z-Taq ${ }^{\mathrm{TM}}$. The amplification was performed in a GeneAmp PCR System 2400 (Perkin-Elmer) programmed for 30 cycles as follows: $1 \mathrm{~s}$ of denaturation at $98^{\circ} \mathrm{C}, 15 \mathrm{~s}$ of primer annealing and extension at $68^{\circ} \mathrm{C}$. The PCR products were analysed by agarose $2.0 \%$ gel electrophoresis in a $0.5 \times$ TBE buffer system.

\section{Southern hybridisation}

After analysis by agarose gel electrophoresis, the PCR products were transferred to a nylon membrane with a Model 785 Vacuum Blotter (BioRad). Hybridisation was performed as follows. Blotted membrane was treated at $68^{\circ} \mathrm{C}$ for $1 \mathrm{~h}$ in a prehybridisation buffer, i.e., $5 \times$ SSC containing skimmed milk $0.25 \% \mathrm{w} / \mathrm{v}, \mathrm{N}-$ laurylsarcosine $0.025 \% \mathrm{w} / \mathrm{v}, \quad \operatorname{SDS} \quad 0.02 \% \mathrm{w} / \mathrm{v}$ and $0.25 \mathrm{mg}$ of salmon sperm DNA denatured by heat treatment $\left(95^{\circ} \mathrm{C}\right.$ for $5 \mathrm{~min}$ followed by rapid chilling on ice). Then, $5 \mu \mathrm{l}$ of the digoxigenin-labelled ily gene fragment denatured by the heat treatment was added to the $5 \times \mathrm{SSC}$ containing skimmed milk $0.25 \% \mathrm{w} / \mathrm{v}, \mathrm{N}-$ laurylsarcosine $0.025 \% \mathrm{w} / \mathrm{v}, \quad \operatorname{SDS} \quad 0.02 \% \mathrm{w} / \mathrm{v}$ and $0.13 \mathrm{mg}$ of heat-denatured salmon sperm DNA, and allowed to react with the blotted membrane at $68^{\circ} \mathrm{C}$ overnight. The probe used in this hybridisation was the digoxigenin-labelled ily gene fragment of $341 \mathrm{bp}$ amplified by PCR with the primer set of ILY-4D Fw and ILY-Cend Bw shown in Fig. 1. Subsequently, the membrane was washed twice with $2 \times$ SSC containing SDS $0.1 \%$ at room temperature for $5 \mathrm{~min}$, twice with $0.1 \times \mathrm{SSC}$ containing SDS $0.1 \%$ at $68^{\circ} \mathrm{C}$ for $5 \mathrm{~min}$ and then once with the washing buffer $-0.1 \mathrm{M}$ maleic acid buffer ( $\mathrm{pH} 7.5$ ) containing $0.15 \mathrm{M} \mathrm{NaCl}$ and Tween 20 $0.3 \% \mathrm{v} / \mathrm{v}$ - at room temperature for $5 \mathrm{~min}$. The washed membrane was dipped into the blocking buffer in a polymer bag containing skimmed milk $1 \% \mathrm{w} / \mathrm{v}$, sodium azide $0.004 \% \mathrm{w} / \mathrm{v}, 0.08 \mathrm{M}$ maleic acid and $0.12 \mathrm{M}$ $\mathrm{NaCl}$. The membrane sealed in the bag was incubated at room temperature for $30 \mathrm{~min}$. The horseradish peroxidase-labelled anti-digoxigenin antibody (Roche Diagnostics, Tokyo, Japan) was diluted to $75 \mathrm{mU} / \mathrm{ml}$ (1 in 10000 dilution) in the blocking buffer and allowed to react with the blotted membrane at room temperature for $30 \mathrm{~min}$ with gentle agitation. Subsequently, the membrane was washed twice with washing buffer at room temperature for $20 \mathrm{~min}$ with gentle agitation. Signals on the washed membrane were detected by chemiluminescence with ImmunoStar Reagents (Wako Pure Chemical Industries, Osaka, Japan).

\section{Sensitivity assay of PCR}

Serial dilutions of $100-0.1 \mathrm{ng}$ of genomic DNA or $\left(1 \times 10^{6}\right)-\left(1 \times 10^{2}\right)$ cells per PCR reaction of $S$. intermedius type strain (NCDO2227) were prepared to estimate the sensitivity of PCR with TaKaRa Z-Taq ${ }^{\mathrm{TM}}$ as a DNA polymerase. PCR conditions were the same as described above. The PCR products were analysed by agarose $2.0 \%$ gel electrophoresis in a $0.5 \times \mathrm{TBE}$ buffer system.

\section{Results}

Genomic dot-blot hybridisation of the type strains of streptococci with the ily gene

Fig. 2 shows a dot-blot hybridisation profile of the type strains (48 strains) of all groups of streptococci and some closely related genera (6 strains) with the ily gene fragment as the probe at low stringency. At high stringency, a strong signal was recognised with the three strains of $S$. intermedius (the type strain NCDO2227, strain UNS38 and strain UNS46) and no signal was found with any other type strains (data not shown). As shown in Fig. 2, under low stringency, a very weak signal was also detected with the type strains of $S$. anginosus, S. constellatus subsp. constellatus, $S$. constellatus subsp. pharyngis and $S$. infantis. No (or a very faint) signal was found with other type strains, despite a significant degree of homology (51.7-60.1\%) between the ily gene and genome-linked streptococcal toxin genes such as pneumolysin ( $S$. pneumoniae) and streptolysin O $(S$. pyogenes). Therefore, although it has been shown that $S$. canis and $S$. dysgalactiae subsp. equisimilis both contain a gene with high homology to the gene for streptolysin O from S. pyogenes $(98.2 \%$ and $98.6 \%$ homology, respectively), it seems that gene(s) with high homology to the ily gene are not present among the other streptococci or closely related genera. Moreover, it has also been shown that the ily gene is ubiquitous within S. intermedius strains [19]. Taken together, these results indicate that specific amplification of the ily gene by PCR is a promising method to rapidly and accurately identify $S$. intermedius strains from among other streptococcal strains from clinical sources. 


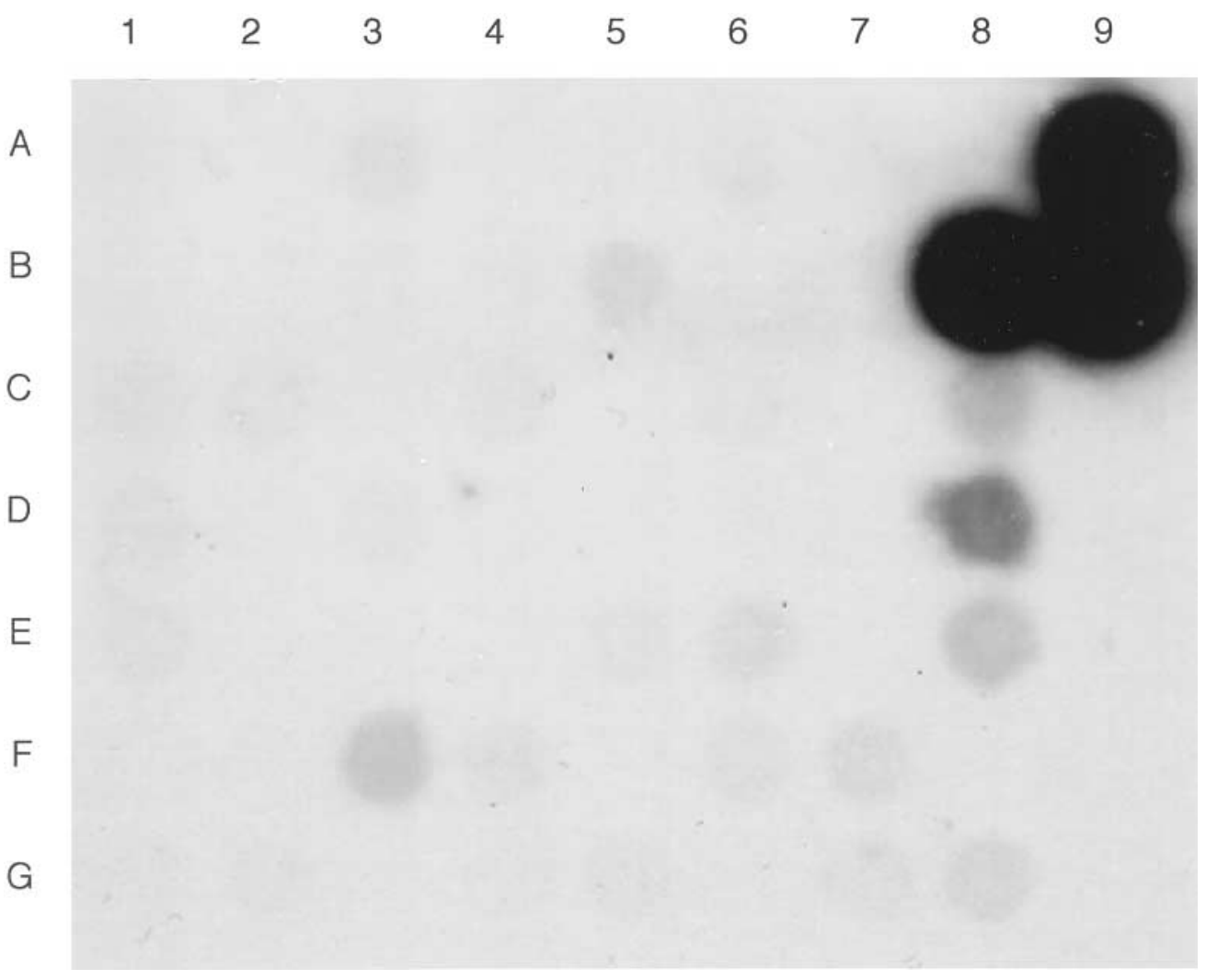

Fig. 2. Dot-blot hybridisation of genomic DNA from the type strains of streptococci and related genera with the ily gene probe. A1, S. acidominimus; B1, S. agalactiae; C1, S. alactolyticus; D1, S. bovis; E1, S. canis; F1, S. criceti; G1, S. cristatus; A2, S. difficilis; B2, S. downei; C2, S. dysgalactiae subsp. equisimilis; D2, S. dysgalactiae subsp. dysgalactiae; E2, S. equi subsp. equi; F2, S. equi subsp. zooepidemicus; G2, S. equinus; A3, S. ferus; B3, S. gallolyticus; C3, S. gordonii; D3, S. hyointestinalis; E3, S. hyovaginalis; F3, S. infantis; G3, S. iniae; A4, S. intestinalis; B4, S. macacae; C4, S. macedonicus; D4, S. mitis; E4, S. mutans; F4, S. oralis; G4, S. parasanguinis; A5, S. parauberis; B5, S. peroris; C5, S. phocae; D5, S. pleomorphus; E5, S. pneumoniae; F5, S. porcinus; G5, S. pyogenes; A6, S. ratti; B6, S. salivarius; C6, S. sanguinis; D6, S. sobrinus; E6, S. suis; F6, S. thermophilus; G6, S. thoraltensis; A7, S. uberis; B7, S. vestibularis; C7, Staph. aureus; D7, Staph. epidermidis; E7, E. faecalis; F7, E. faecium; G7, L. lactis; A8, G. haemolysans; B8, S. intermedius; C8, S. anginosus; D8, S. constellatus subsp. constellatus; E8, S. anginosus group 2 (MAS624); F8, S. constellatus subsp. pharyngis; G8, S. constellatus subsp. pharyngis (M5823); A9, S. intermedius (UNS38); B9, S. intermedius (UNS46). All strains except E8, G8, A9 and B9 are the type strain of each species.

\section{PCR of the ily gene fragment with extracted genomic DNA as the template}

The study first examined whether $S$. intermedius can be detected specifically by PCR with genomic DNA extracted from streptococci. Genomic DNA from the type strains of streptococcal species (48 strains), species from related genera (6 strains) and from clinical and reference AGS strains including $S$. intermedius derived from various sites (88 strains) were used as templates. Six primer sets were designed and used to test the specificity of the amplification of the ily gene by PCR. Five sets were a combination of the primers corresponding to the sequence within the ORF of ILY including the primer set which was used previously to analyse the distribution of the ily gene among AGS [19] and the other was a set (ILY-4D Fw and ILY-wholeC $\mathrm{Bw}$ ) for amplifying the sequence which included the C-terminal side of ORF of ILY and its $3^{\prime}$ flanking region (819-bp fragment shown in Fig. 1 as no. 3). Fig. 3 shows the PCR amplification pattern of the ily gene fragment with primers ILY-4D Fw and ILY-
wholeC Bw against the streptococcal type strains and other related genera. Only primers ILY-4D Fw and ILYwholeC $\mathrm{Bw}$ gave a clear $S$. intermedius-specific amplicon; the other five primer sets which were expected to amplify a part of the ORF region of ILY showed one or more additional non-specifically amplified band(s) in other groups of streptococci besides the specific amplification of the $i l y$ gene fragment within $S$. intermedius strains (data not shown). Therefore, primers ILY-4D Fw and ILY-wholeC Bw were selected for the identification of $S$. intermedius by PCR and were used subsequently throughout this study. Furthermore, as shown in Table 1 , only $S$. intermedius strains were positive for amplification of the ily gene fragment. These results suggest that the present PCR system with the ily gene as a species marker gene could provide a clear and rapid method for the unambiguous identification of $S$. intermedius strains.

Subsequently, the study also investigated whether the ily gene could be detected in all strains of $S$. intermedius among AGS by the present PCR system 


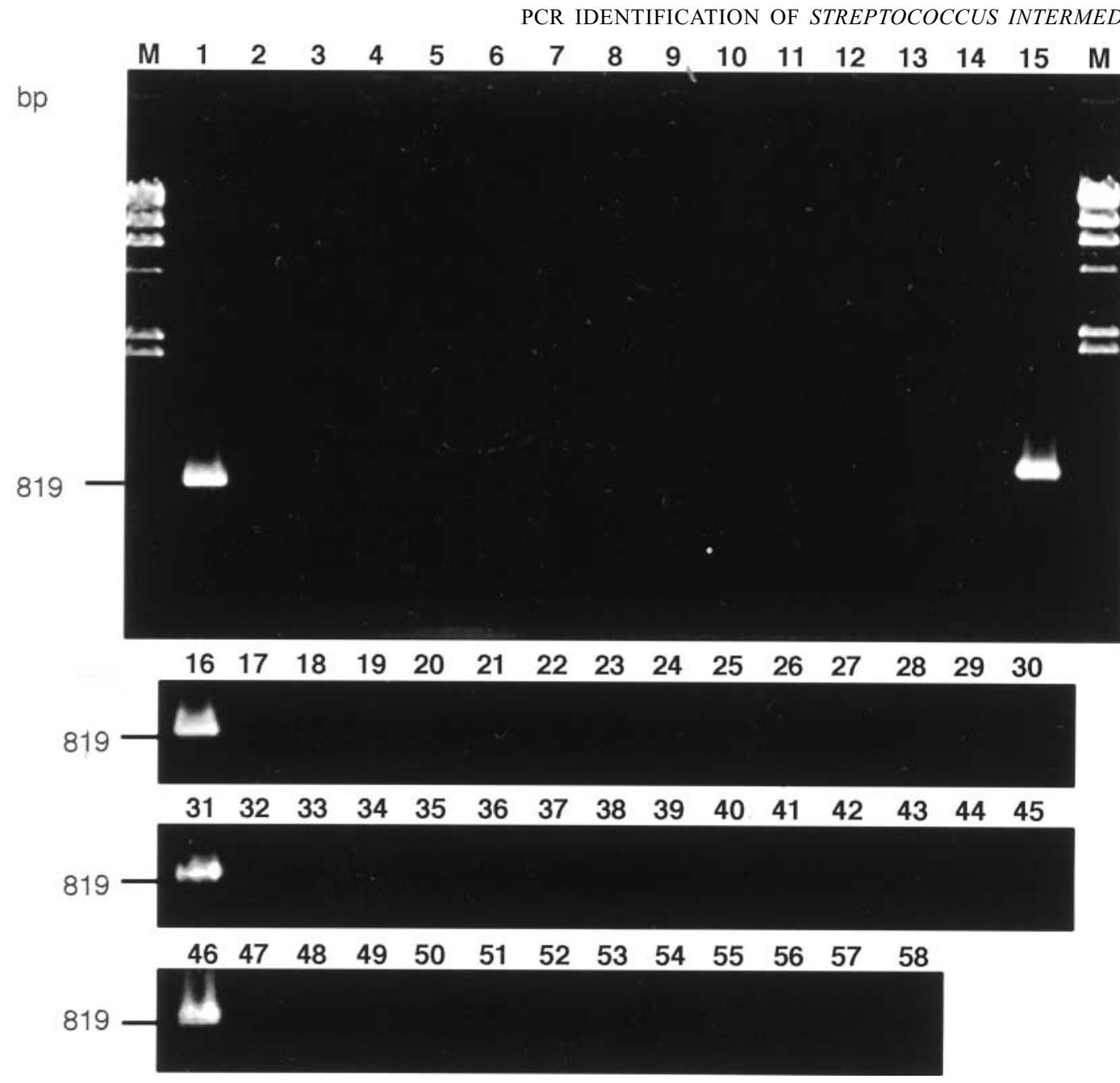

Fig. 3. Agarose gel electrophoresis of PCR products amplified from the genomic DNA of streptococci and related genera with the PCR primer set specific for the ily gene. Lanes: 1, 15, 16, 31, 46, S. intermedius; 2, S. anginosus; 3, S. constellatus subsp. constellatus; $\mathbf{4}$, S. acidominimus; $\mathbf{5}$, S. agalactiae; 6, S. alactolyticus; $\mathbf{7}, S$. bovis; $\mathbf{8}$, S. canis; $\mathbf{9}$, S. criceti; $\mathbf{1 0}, S$. cristatus; $\mathbf{1 1}, S$. difficilis; 12, S. downei; 13, S. dysgalactiae subsp. equisimilis; 14, S. dysgalactiae subsp. dysgalactiae; 17, S. equi subsp. equi; 18, $S$. equi subsp. zooepidemicus; 19, S. equinus; 20, S. ferus; 21, S. gallolyticus; 22, S. gordonii; 23, S. hyointestinalis; 24, S. hyovaginalis; 25, S. infantis; 26, S. iniae; 27, S. intestinalis; 28, S. macacae; 29, S. macedonicus; 30, S. mitis; 32, S. mutans; 33, S. oralis; 34, S. parasanguinis; 35, S. parauberis; 36, S. peroris; 37, S. phocae; 38, S. pleomorphus; 39, S. pneumoniae; 40, S. porcinus; 41, S. pyogenes; 42, S. ratti; 43, S. salivarius; 44, S. sanguinis; 45, S. sobrinus; 47, S. suis; 48, S. thermophilus; 49, S. thoraltensis; 50, S. uberis; 51, S. vestibularis; 52, Staph. aureus; 53, Staph. epidermidis; 54, E. faecalis; 55, E. faecium; 56, L. lactis; 57, G. haemolysans; 58, S. constellatus subsp. pharyngis; M, $\lambda$ DNA HindIII cut. All strains are the type strain of each species.

with the extracted genomic DNA of clinical AGS strains (55 strains) derived from human tonsillitis. Recently, several $\beta$-haemolytic, Lancefield group C strains with a biotype similar to $S$. intermedius were found to be genetically different from $S$. intermedius, and have been proposed as a new subspecies (pharyngis) within $S$. constellatus [10]. These strains are

Table 1. PCR amplification of the ily gene fragment in reference strains of AGS

\begin{tabular}{lc}
\hline Species (n) & $\begin{array}{c}\text { Amplification of 819-bp } \\
\text { fragment (\% positive) }\end{array}$ \\
\hline$S$. anginosus $\left(11^{*}\right)$ & $-(0)$ \\
$S$. anginosus group $2(1)$ & $-(0)$ \\
$S$. constellatus subsp. constellatus $\left(11^{*}\right)$ & $-(0)$ \\
$S$. constellatus subsp. pharyngis $\left(2^{*}\right)$ & $-(0)$ \\
$S$. intermedius $\left(12^{*}\right)$ & $+(100)$ \\
\hline
\end{tabular}

*Including type strain. sufficiently similar to $S$. intermedius in biochemical test reactions to cause confusion when employing commercial identification test kits. Therefore, the clinical strains examined in this study were re-tested according to the criteria reported by Whiley et al. [10] and the result of PCR detection of the ily gene fragment was compared with that of the biochemical and immunological identification method which consisted of haemolytic reaction on horse blood agar, Lancefield grouping and glycosidase assays [10,11] (Table 2). As shown in Table 2, and as expected, the result of the biochemical and immunological identification according to the new criteria differed from those obtained with the Rapid ID32 Strep test kit, especially in the identification of $S$. intermedius and $S$. constellatus subsp. pharyngis. There was $58.3 \%$ agreement between biochemical and immunological identification methods and Rapid ID32 Strep for $S$. intermedius identification. However, the 
Table 2. Comparison of the results of $S$. intermedius identification by three methods

\begin{tabular}{|c|c|c|c|}
\hline Species by RM (n) & Species by RID (n) & $\begin{array}{l}\text { PCR of the } \\
\text { ily gene* (n) }\end{array}$ & $\begin{array}{l}\text { Percentage matching } \\
\text { of } S \text {. intermedius } \\
\text { identification between } \\
\text { RM and PCR }\end{array}$ \\
\hline \multirow[t]{2}{*}{ S. anginosus (16) } & S. anginosus (15) & $-(15)$ & $\ldots$ \\
\hline & $\begin{array}{l}\text { S. constellatus } \\
\quad \text { subsp. constellatus }\end{array}$ & $-(1)$ & $\cdots$ \\
\hline \multirow{3}{*}{$\begin{array}{l}\text { S. constellatus } \\
\quad \text { subsp. constellatus (20) }\end{array}$} & S. constellatus & & \\
\hline & subsp. constellatus (19) & $-(19)$ & $\ldots$ \\
\hline & S. intermedius (1) & $-(1)$ & $\cdots$ \\
\hline \multirow{2}{*}{$\begin{array}{l}\text { S. constellatus } \\
\text { subsp. pharyngis (9) }\end{array}$} & S. anginosus (5) & $-(5)$ & $\ldots$ \\
\hline & S. intermedius (4) & $-(4)$ & $\ldots$ \\
\hline \multirow[t]{2}{*}{ S. intermedius (9) } & S. anginosus (2) & $+(2)$ & 100 \\
\hline & S. intermedius (7) & $+(7)$ & 100 \\
\hline UI (1) & $S$. anginosus (1) & $-(1)$ & $\ldots$ \\
\hline
\end{tabular}

RM, the reference identification method [11,21]; RID, Rapid ID32 Strep; UI, unidentified Streptococcus sp.

${ }^{*}$ The same results were obtained in PCR with whole bacterial cells in colonies as with template DNA.

PCR approach showed $100 \%$ agreement with the identification of $S$. intermedius by the recently published [10] identification criteria.

\section{Direct colony PCR of the ily gene fragment}

To improve the rapidity of identification by this PCR system, the study attempted to use a single bacterial colony as a template. Fig. 4a shows a typical pattern of the detection of $S$. intermedius strains within the reference strains of AGS by direct colony PCR. The expected 819-bp amplicon was detected only in $S$. intermedius strains. Subsequently, Southern hybridisation was used to confirm that the fragments amplified by PCR were those ampified from the ily gene (Fig. $4 b)$. It also confirmed that the identification results shown in Table 2 with 55 clinical isolates were in complete agreement with the direct colony PCR approach. Furthermore, use of a highly efficient DNA polymerase, TaKaRa Z-Taq ${ }^{\mathrm{TM}}$, instead of ordinary Taq DNA polymerase resulted in a shortened total PCR programme (18 min) to achieve a positive PCR result.

\section{Sensitivity of PCR amplification of the ily gene fragment}

The sensitivity of the present PCR method was determined by performing PCR with whole cells or
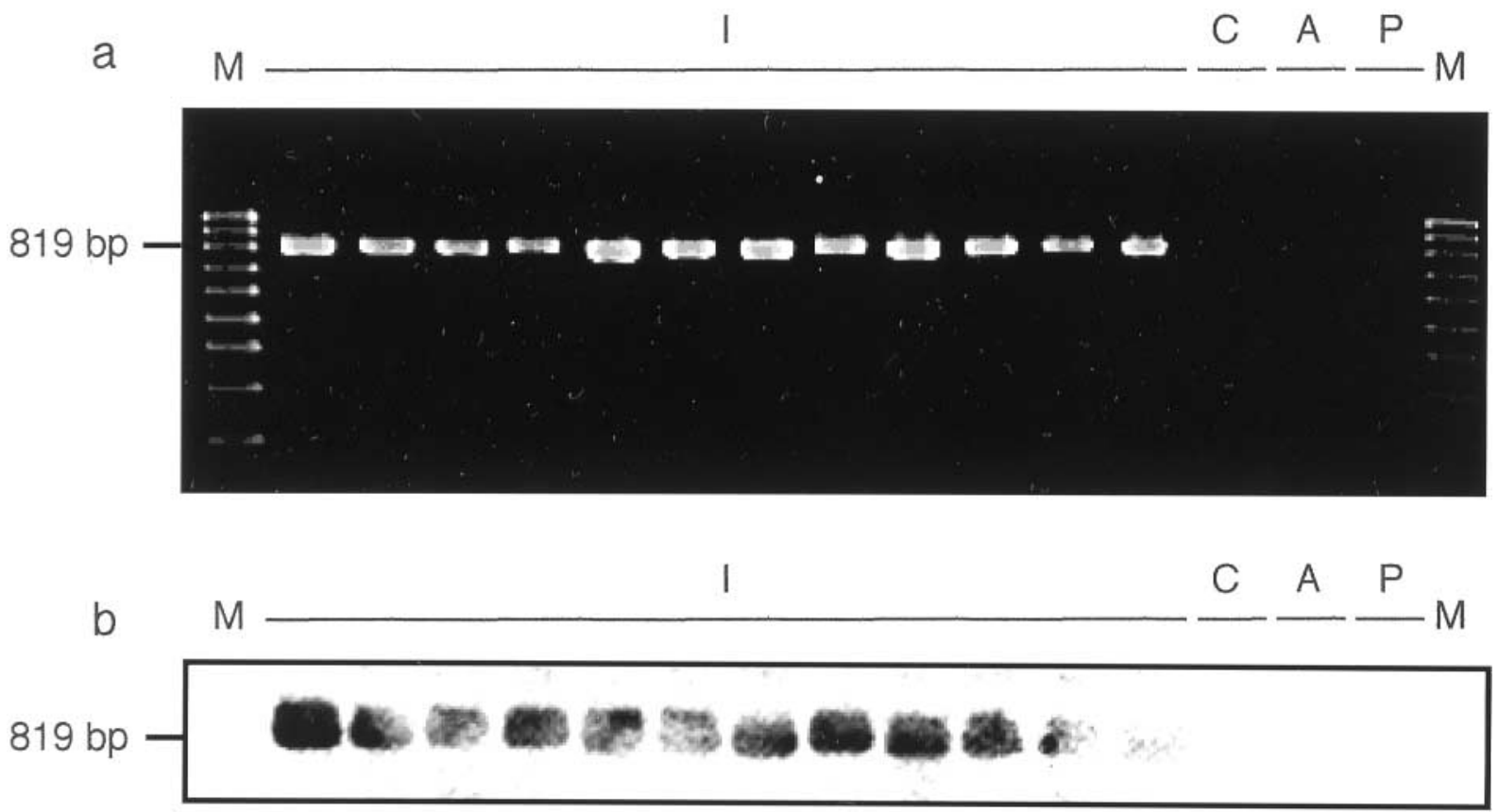

Fig. 4. Agarose gel electrophoresis of PCR products amplified from the colonies of AGS reference strains and Southern hybridisation of the PCR products with the ily gene probe. (a) Result of the colony direct PCR with reference strains of AGS. (b) Result of Southern hybridisation of the PCR products shown in (a) with a 341-bp fragment of the ily gene. I, S. intermedius strains: NCDO2227 (the type strain), PC941, AM47, DP102, UNS35, GN6146, PC574, UNS38, UNS46, A4676a, AC4720, HARDYDAVID T1 from left to right; $\mathbf{C}$, the type strain of $S$. constellatus subsp. constellatus; $\mathbf{A}$, the type strain of $S$. anginosus; $\mathbf{P}$, the type strain of S. constellatus subsp. pharyngis; M, 100-bp ladder marker. 
extracted genomic DNA from the type strain, $S$. intermedius NCDO2227. The minimum detectable level of extracted genomic DNA by PCR with TaKaRa Z-Taq was $0.1 \mathrm{ng}$ DNA (Fig. 5a). When bacterial whole cells were used, $1 \times 10^{5}$ cells was the minimum number required for detection (Fig. 5b).

\section{Discussion}

AGS, including $S$. intermedius, are known to be a heterogeneous streptococcal group [21-23]. Recently, an AGS strain formerly described as atypical $\beta$ haemolytic, Lancefield group $\mathrm{C} S$. anginosus with similar biochemical characteristics to $S$. intermedius was proposed as ' $S$. constellatus subsp. pharyngis' [10]. This subspecies is associated with pharyngitis and can be confused with $S$. intermedius or $S$. anginosus by commercial identification kits such as Rapid ID32 Strep and Fluo-Card Milleri. Therefore, for accurate identification of $S$. intermedius, the current biochemical and metabolic reactions for identification of AGS in commercial identification kits need to be revised (e.g., by the inclusion of a test for sialidase activity). Thus, this study attempted to develop a simple, rapid and reliable identification method for $S$. intermedius employing PCR. It has confirmed that the ily gene can be used as a species marker gene. As shown by dot-blot hybridisation and by PCR amplification of the ily gene, the present study demonstrated that neither this gene nor any with significant homology existed outside the species $S$. intermedius, thereby demonstrating its suitability as a reliable species marker for identification on a routine basis. Indeed, the results of
PCR with 33 reference strains and 55 clinical AGS isolates from tonsillitis revealed that identification of $S$. intermedius by this PCR approach was in agreement with the results obtained with the identification scheme of Whiley et al. $[10,11]$. On the other hand, the percentage agreement with results obtained by a commercial identification kit (Rapid ID32 Strep), was only $58.3 \%$, which was essentially the same value as reported previously [14], again demonstrating the great improvement in identification of this species that this approach represents.

Subsequently, to simplify the entire PCR methodology, the test was developed on the basis of single colony PCR, thus circumventing the need for lengthy and tedious purification of template genomic DNA. With this approach, the results obtained were the same as those obtained with purified template. Furthermore, by making use of a highly efficient DNA polymerase, TaKaRa Z-Taq ${ }^{\mathrm{TM}}$, the study succeeded in reducing the programming time for PCR to $<20 \mathrm{~min}$. PCR sensitivity with purified genomic DNA as the template was $>0.1 \mathrm{ng}$ DNA/PCR reaction. The genome sizes of streptococci such as $S$. equi, S. mutans, S. pneumoniae and $S$. pyogenes are in the range $1.98-2.3 \mathrm{Mbp}$ [24]. Thus, $0.1 \mathrm{ng}$ of genomic DNA roughly corresponds to the genomic DNA from $4.1 \times 10^{4}$ cells if the genome size of $S$. intermedius is taken to be the average of the four values in the range shown above (i.e., 2.17 Mbp). This estimated cell number of the detection limit was essentially consistent with the experimental number, $1 \times 10^{5}$ cells/PCR reaction if cell lysis by heat treatment was not completed. A single colony on an agar plate containing more than the cell number
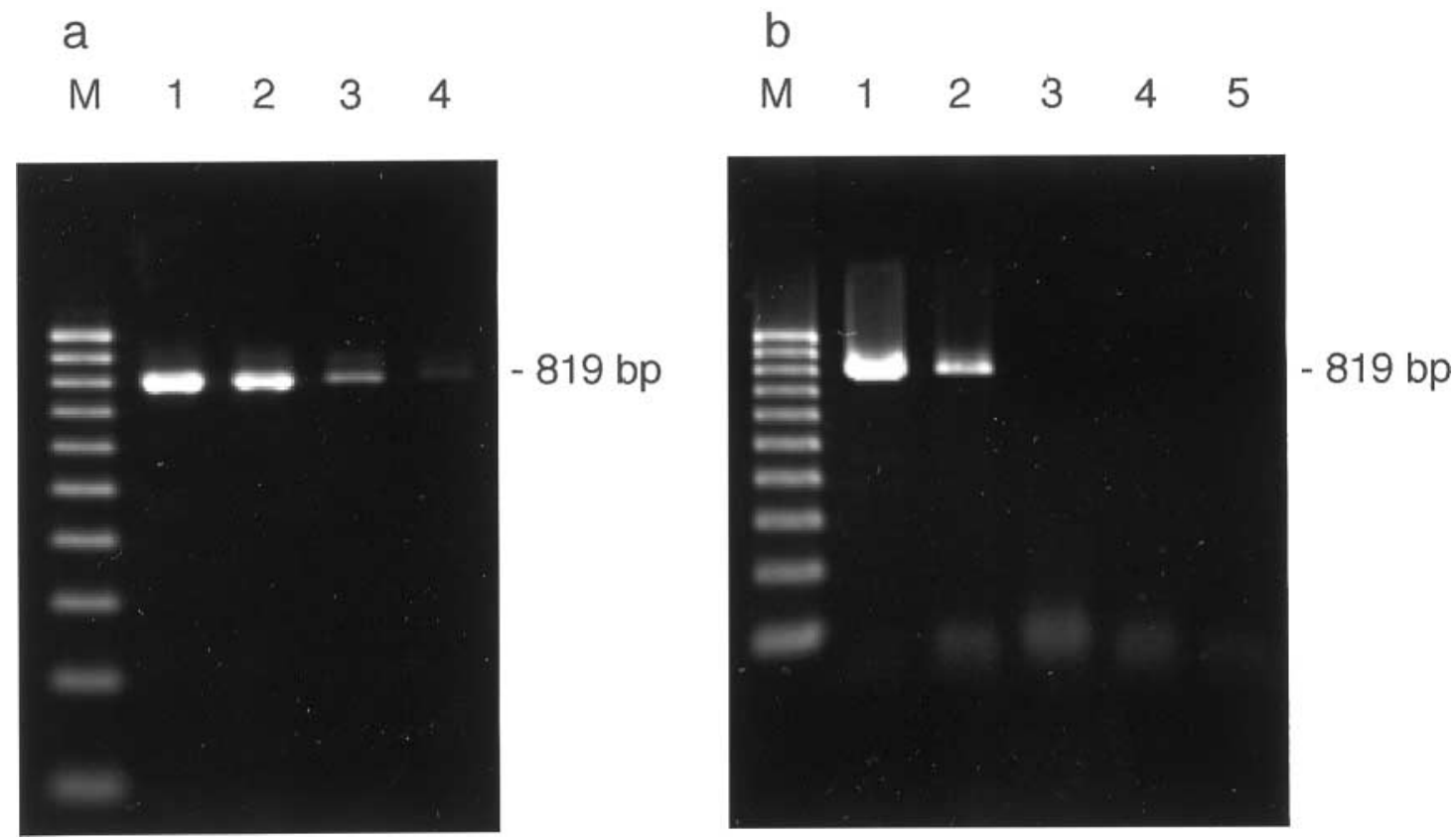

Fig. 5. Sensitivity of the PCR system with TaKaRa Z-Taq. (a) PCR with purified genomic DNA as a template. Lanes: 1, $100 \mathrm{ng}$ DNA; 2, $10 \mathrm{ng}$; 3, $1 \mathrm{ng}$; 4, $0.1 \mathrm{ng}$; M, 100-bp ladder marker. (b) PCR with whole bacterial cells as a template. Lanes: 1, $1 \times 10^{6}$ cells; $2,1 \times 10^{5}$ cells; $\mathbf{3}, 1 \times 10^{4}$ cells; $\mathbf{4}, 1 \times 10^{3}$ cells; $\mathbf{5}, 1 \times 10^{2}$ cells; $\mathbf{M}, 100$-bp ladder marker. The type strain, $\mathrm{NCDO} 2227$, was used in these experiments. 
required in the present PCR system is sufficient for the detection of the ily gene for $S$. intermedius identification.

The present PCR system is superior in rapidity to the standard biochemical and immunological identification method and also superior in accuracy to commercial identification kits such as Rapid ID32 Strep or Fluo-Card Milleri. However, optimisation of sample preparation from the potentially different clinical specimens in which $S$. intermedius might be found may be necessary for the routine application of this PCR method for identification.

We are grateful to Makoto Hiwasa for technical assistance. This work was supported in part by Grant-in-Aid for Scientific Research (12672151) from the Ministry of Education, Science, Sports and Culture, Japan.

\section{References}

1. Bateman NT, Eykyn SJ, Phillips I. Pyogenic liver abscess caused by Streptococcus milleri. Lancet 1975; 1: 657-659.

2. Poole PM, Wilson G. Streptococcus milleri in the appendix. J Clin Pathol 1977; 30: 937-942.

3. De Louvois J. Bacteriological examination of pus from abscesses of the central nervous system. J Clin Pathol 1980; 33: $66-71$.

4. Van der Auwera P. Clinical significance of Streptococcus milleri. Eur J Clin Microbiol 1985; 4: 386-390.

5. Singh KP, Morris A, Lang SD, MacCulloch DM, Bremner DA. Clinically significant Streptococcus anginosus (Streptococcus milleri) infections: a review of 186 cases. $N Z$ Med J 1988; 101: $813-816$.

6. Gossling J. Occurrence and pathogenicity of the Streptococcus milleri group. Rev Infect Dis 1988; 10: 257-285.

7. Ruoff KL. Streptococcus anginosus ("Streptococcus milleri"): the unrecognized pathogen. Clin Microbiol Rev 1988; 1: 102-108.

8. Brook I, Frazier EH. Microaerophilic streptococci as a significant pathogen: a twelve-year review. J Med 1994; 25 : 129-144.

9. Whiley RA, Hardie JM. DNA-DNA hybridization studies and phenotypic characteristics of strains within the 'Streptococcus milleri group'. J Gen Microbiol 1989; 135: 2623-2633.

10. Whiley RA, Hall LMC, Hardie JM, Beighton D. A study of small-colony, $\beta$-haemolytic, Lancefield group C streptococci within the anginosus group: description of Streptococcus constellatus subsp. pharyngis subsp. nov., associated with the human throat and pharyngitis. Int J Syst Bacteriol 1999; 49: $1443-1449$.

11. Whiley RA, Fraser H, Hardie JM, Beighton D. Phenotypic differentiation of Streptococcus intermedius, Streptococcus constellatus, and Streptococcus anginosus strains within the "Streptococcus milleri group". J Clin Microbiol 1990; 28: 1497-1501.

12. Socransky SS, Haffajee AD. Microbiology of periodontal disease. In: Lindhe J, Karring T, Lang NP (eds) Clinical periodontology and implant dentistry, 3rd edn. Copenhagen, Munksgaard. 1997: 138-188.

13. Jacobs JA, Stobberingh EE. Species identification of "Streptococcus milleri" with the Rapid ID 32 Strept system. Med Microbiol Lett 1994; 3: 315-322.

14. Lima A, Alarcon T, Jimenez ML, Lopez-Brea M. Comparison of three methods for identification of Streptococcus milleri group isolates to species level. Eur J Clin Microbiol Infect Dis 2000; 19: $128-131$.

15. Flynn CE, Ruoff KL. Identification of "Streptococcus milleri" group isolates to the species level with a commercially available rapid test system. $J$ Clin Microbiol 1995; 33: 2704-2706.

16. Sultana F, Kawamura Y, Hou X-G, Shu S-E, Ezaki T. Determination of 23S rRNA sequences from members of the genus Streptococcus and characterization of genetically distinct organisms previously identified as members of the Streptococcus anginosus group. FEMS Microbiol Lett 1998; 158: $223-$ 230.

17. Jacobs JA, Schot CS, Bunschoten AE, Schouls LM. Rapid species identification of "Streptococcus milleri" strains by line blot hybridization: identification of a distinct 16S rRNA population closely related to Streptococcus constellatus. J Clin Microbiol 1996; 34: 1717-1721.

18. Nagamune H, Ohnishi C, Katsuura A et al. Intermedilysin, a novel cytotoxin specific for human cells, secreted by Streptococcus intermedius UNS46 isolated from a human liver abscess. Infect Immun 1996; 64: 3093-3100.

19. Nagamune H, Whiley RA, Goto $\mathrm{T}$ et al. Distribution of the intermedilysin gene among the Anginosus group streptococci and correlation between intermedilysin production and deepseated infection with Streptococcus intermedius. $J$ Clin Microbiol 2000; 38: 220-226.

20. Whiley RA, Beighton D. Emended descriptions and recognition of Streptococcus constellatus, Streptococcus intermedius, and Streptococcus anginosus as distinct species. Int $J$ Syst Bacteriol 1991; 41: 1-5.

21. Whiley RA, Duke B, Hardie JM, Hall LMC. Heterogeneity among 16S-23S rRNA intergenic spacers of species within the 'Streptococcus milleri group'. Microbiology 1995; 141: 14611467.

22. Whiley RA, Hall LMC, Hardie JM, Beighton D. Genotypic and phenotypic diversity within Streptococcus anginosus. Int $J$ Syst Bacteriol 1997; 47: 645-650.

23. Bartie KL, Wilson MJ, Williams DW, Lewis MAO. Macrorestriction fingerprinting of "Streptococcus milleri" group bacteria by pulsed-field gel electrophoresis. J Clin Microbiol 2000; 38: 2141-2149.

24. Microbial genomes Blast databases, National Center for Biotechnology Information, National Library of Medicine, National Institute of Health, Bethesda, MD, USA. 